\title{
PERLINDUNGAN HUKUM TERHADAP PELAKU PEMBUNUHAN BEGAL ATAS DASAR PEMBELAAN TERPAKSA
}

\author{
Anak Agung Gede Agung, A. A. Sagung Laksmi Dewi, I Made Minggu Widyantara \\ Fakultas Ilmu Hukum, Universitas Warmadewa, Bali - Indonesia \\ anakagung1967@gmail.com, laksmidewi29@gmail.com, mademinggu21@gmail.com
}

\begin{abstract}
Abstrak
Tindak pidana adalah perbuatan yang dilarang dalam undang-undang dan dikenakan sanksi. Tidak semua perbuatan yang melanggar dari ketentuan Undang- undang dapat dipidana, terdapat dalam pasal 49 Kitab Undang-Undang Hukum Pidana yang menyatakan alasan penghapusan pidana. Seseorang yang menjadi korban tindak pidana pembegalan dalam keadaan mendesak mengancam nyawanya melakukan perbuatan pembelaan tidak dipidana. Penelitian ini dilakukan dengan tujuan mengungkap bagaimanakah suatu perbuatan pidana dapat dikategorikan sebagai pembelaan terpaksa dan bagaimanakah perlindungan hukum bagi pelaku pembunuhan begal atas dasar pembelaan terpaksa. Tipe penelitian yang digunakan adalah penelitian hukum normatif. Hasil penelitian ini menunjukan bahwa suatu perbuatan pembelaan terpaksa tidak dapat dikenakan hukuman sesuai dengan pasal 49 Kitab Undang-Undang Hukum Pidana yang menyatakan perbuatan pidana dilakukan dengan keadaan yang mengancam atau serangan saat itu juga, seperti halnya seorang korban pembegalan melakukan pembelaan diri. Hakim sebagai penegak hukum yang memeriksa dan memutuskan suatu hukuman dapat melihat bukti-bukti dari perbuatan pelaku pembelaan diri yang memenuhi unsur-unsur pembelaan terpaksa. Hakim juga mempertimbangkan alasan-alasan pelaku yang dapat memperingan, apalagi pelaku yang melakukan pembelaan diri masih tergolong anak. Kepada aparat penegak hukum khususnya hakim dalam menjatuhkan hukuman terhadap pelaku lebih memperhatikan seseorang melakukan pembelaan terpaksa sehingga terciptanya keadilan.
\end{abstract}

Kata Kunci: Pembelaan Terpaksa, Pembunuhan, Perlindungan Hukum

\begin{abstract}
A criminal act is an act that is prohibited by law and is subject to sanctions. Not all acts that violate the provisions of the law can be convicted, as contained in article 49 of the Criminal Code which was once called a criminal penalty. A person who is a victim of a criminal act of ransom in an affected situation which threatens his life who commits the act shall not be punished. This research was conducted with the aim of revealing how an act can be categorized as a defense and how is the legal protection for the perpetrator of murder on the basis of defense. The type of research used is normative legal research. The results of this study indicated that an act which states that it cannot be charged in accordance with Article 49 of the Criminal Code, is that a criminal act is committed in a threatening situation or an immediate attack, such as a victim of tampering with self-defense. Judges as law enforcers who examine and decide on evidence that can see evidence of the perpetrator's actions of self-defense that meet the elements of the defense. The judge also considered the reasons for the offender that could make it easier, especially since the perpetrator who did self-defense was still classified as a child. To law enforcement officials, judges in defending offenders who pay more attention to someone who is doing it so that justice can be created.
\end{abstract}

Keywords: Forced Defense, Murder, Legal Protection

\section{PENDAHULUAN}

Indonesia merupakan negara hukum yang segala sesuatu perbuatan seseorang harus bedasarkan hukum yang berlaku (Usman, 2014). Hal ini terdapat pada pasal 1 ayat (3) Undang-Undang Dasar 1945. Dengan demikian, kegiatan atau perbuatan seseorang telah diatur di dalam peraturan perundangundangan yang berlaku. Dengan adanya aturan-aturan atau perundangan-undangan terciptanya tujuan negara Indonesia yang terdapat dalam Pembukaan Undang-Undang dasar Tahun 1945 pada alenia ke IV yang mencerminkan Indonesia adalah negara yang menjunjung tinggi demokrasi. Indonesia yang menganut sistem demokrasi yang menjunjung tinggi setiap hak asasi manusia, yaitu hak-hak dari warga negaranya, sehingga negara harus menjamin keadilan bagi seluruh warga negaranya agar mendapat keadilan atas hak-hak setiap warga negara. 
Salah satu terciptanya negara adalah adanya rakyat atau warga negara seperti negara Indonesia. Negara harus menjamin hak-hak dari setiap warga negara mulai dari kebutuhan hidupnya hingga keamanan bagi warga negara agar terciptanya keadilan, kesejahteraan dan kemakmuran bagi seluruh warga negara, sehingga tercapainya tujuan dari negara (Pratiwi, Ariani, \& Heryansyah, 2019). Namun ada batasan hak-hak setiap warga negara mengingat untuk menghormati hak-hak orang lain, tidak semata-mata kebebasan hak asasi manusia diberikan oleh negara namun ada batasan yang perlu diterapkan. Oleh karena itu, negara dalam hal ini mengatur setiap perbuatan manusia dengan aturanaturan yang berlaku. Indonesia telah mempunyai hukum yang mengatur segala perbuatan manusia yang tertuang dalam Kitab Undang-Undang Hukum Pidana dan Undang-Undang yang mengatur di luar Kitab Undang-Undang Hukum Pidana.

Di Indonesia yang terdiri dari kurang lebih 265 juta jiwa penduduk yang memerlukan kebutuhan hidup sehari-hari, tidak jarang seseorang melakukan tindak pidana untuk mendapatkan atau merampas harta benda milik orang lain secara cepat (instan). Ini dilakukan seseorang untuk memenuhi kebutuhan hidupnya. Banyak terjadi tindak pidana di Indonesia yang salah satunya adalah tindak pidana begal. Tindak pidana begal merupakan kejahatan yang dilakukan oleh satu atau lebih pelaku dengan merampas barang-barang milik korbanya pada malam hari dengan mengancam menggunakan senjata tajam hingga melukai korbanya agar tidak dapat melakukan perlawanan. Biasanya pelaku merencanakan terlebih dahulu kejahatan yang dilakukan. Target dari pelaku biasanya seseorang yang berkendara sendiri terutama seorang perempuan. Tidak jarang pelaku segan-segan membunuh korbanya agar menghilangkan jejak kejahatannya. Tindak pidana begal termasuk dalam kejahatan harta benda yang terdapat dalam buku II Kitab Undang-Undang Hukum Pidana pada pasal 365.

Namun dalam kenyataannya tidak semua korban hanya berdiam diri untuk dirampas harta bendanya. Ada beberapa korban yang melakukan perlawanan untuk membela diri atau melawan pelaku begal tersebut. Korban yang merasa terancam keselamatan dirinya tidak segan-segan melakukan serangan balik terhadap pelaku begal, sehingga pelaku begal mengalami luka-luka akibat perlawanan atau pembelaan diri tersebut, bahkan hingga mengalami kematian.

Pembelaan diri yang dilakukan oleh korban termasuk dalam tindak pidana yang memenuhui unsur-unsur tindak pidana. Suatu perbuatan tidak dapat dijatuhi hukuman terhadap diri koban yang dalam hal ini sebagai pelaku pembelaan diri yang mengakibatkan luka-luka hingga kematian. Perbuatan pembelaan diri yang dilakukan oleh korban tindak pidana mendapat perlindungan hukum atas perbuatannya (Utayo, 2013).

Dalam Kitab Undang-Undang Hukum Pidana menyebutkan suatu tindak pidana yang dilakukan atas dasar pembelaan diri atau pembelaan terpaksa tidak dapat dipidana (Dumgair, 2016; Marselino, 2020; Tabaluyan, 2015). Pembelaan terpaksa dilakukan seseorang yang keadaan dalam mendesak atau terancam keselamatan dirinya ataupun orang lain. Tidak hanya pembelaan diri atas keselamatan namun pembelaan dapat dilakukan terhadap orang lain juga, jika keadaannya terancam dan barang-barang atau benda yang bersifat harta kekayaan.

Pembuktian seseorang yang melakukan pembelaan terpaksa hanya dapat dibuktikan berdasarkan hasil pemeriksaan dan putusan oleh pengadilan, dalam pemeriksaan di pengadilan harus berdasarkan alat-alat bukti yang ditemukan di tempat kejadian perkara (TKP), kemudian mendengarkan keterangan dari saksi- saksi, sehingga hakim dapat mepertimbangkan penjatuhan hukuman terhadap pelaku pembelaan terpaksa, dimana pelaku mendapatkan keringanan hukuman atau alasan penghapusan pidana.

Berdasarkan pemaparan dari latar belakang tersebut, maka penelitian ini dilakukan dengan tujuan mengungkap bagaimanakah suatu perbuatan pidana dapat dikategorikan sebagai pembelaan terpaksa dan bagaimana perlindungan hukum bagi pelaku pembunuhan begal atas dasar pembelaan terpaksa.

\section{METODE PENELITIAN}

Penelitian ini dilakukan dengan menggunakan metode penelitian hukum normatif, dan pendekatan yang digunakan adalah pendekatan konseptual. Sumber bahan hukum yang digunakan sebagai bahan hukum primer terdiri dari Undang-Undang Dasar Negara Republik Indonesia Tahun 1945, Kitab Undang-Undang Hukum Pidana (Undang-Undang Nomor 1 Tahun 1946, Kitab Undang-Undang Hukum Acara Pidana (Undang-Undang Nomor 8 Tahun 1981), bahan hukum sekunder terdiri dari pustaka yang meliputi buku-buku, artikel, dan dokumen-dokumen, serta internet yang berkaitan dengan permasalahan, serta bahan hukum tersier yaitu bahan hukum yang mendukung bahan hukum primer dan bahan hukum sekunder. Teknik pengumpulan bahan hukum dilakukan dengan cara 
mempelajari buku- buku kepustakaan untuk memperoleh bahan hukum sekunder yang dilakukan dengan cara menginventarisasi dan mempelajari serta mengutip dari buku-buku dan peraturan perundang-undangan yang berkaitan. Setelah bahan hukum terkumpul, maka dilakukan pencatatan, meringkas dan mengulas sesuai dengan masalah. Kemudian, bahan hukum terkumpul maka dilakukan analisis secara kualitatif yaitu suatu pembahasan yang dilakukan dengan cara memadukan antara penelitian kepustakaan serta menafsirkan dan mendiskusikan. Selanjutnya, data disajikan menggunakan metode informal.

\section{HASIL DAN PEMBAHASAN}

\section{Perbuatan Pidana yang Dapat Dikategorikan sebagai Pembelaan Terpaksa}

Indonesia merupakan negara hukum yang memiliki hukum tersendiri yaitu hukum pidana. Dalam Bahasa belanda hukum pidana yang berarti Strafrecht, hukum pidana sering juga disebut dengan Kitab Undang-Undang Hukum Pidana (KUHP). Pengertian hukum pidana menurut Soedarto yang mengartikan bahwa Hukum pidana memuat aturan-aturan hukum yang mengikatkan kepada perbuatan-perbuatan yang memenuhi syarat tertentu suatu akibat yang berupa pidana (Sastrawidjaja, 1990). Menurut penulis pengertian hukum pidana adalah keseluruhan peraturan yang berisi larangan atau hal-hal yang tidak boleh dilakukan akan suatu perbuatan yang sudah ditentukan oleh undangundang yang bila dilanggar akan diancam atau dikenakan sanksi pidana.

Segala sesuatu perbuatan manusia dalam hal warga negara Indonesia atau warga negara asing yang tinggal di Kawasan negara Indonesia haruslah berpedoman pada aturan hukum yang berlaku di Indonesia. Mengingat banyaknya pelanggaran-pelanggaran atau tindak pidana yang terjadi di Indonesia, pengertian tindak pidana menurut Moeljatno (2007) yang menurut istilah beliau yakni perbuatan pidana adalah Perbuatan yang melanggar yang dilarang oleh suatu aturan hukum, larangan mana disertai ancaman (sanksi) yang berupa pidana tertentu bagi siapa saja yang melanggar larangan tersebut (Moeljatno, 2007). Dari pengertian yang dikemukakan oleh Moeljatno, (2007) terdapat unsur-unsur yang tindak pidana yaitu:

1. Adanya Perbuatan

Menurut ilmu pengetahuan hukum pidana, suatu perbuatan tertentu manusia yang dilarang oleh ketentuan pidana (melakukan perbuatan) disebut dengan Commision.

2. Ada Sifat Melawan Hukum

Melawan hukum dapat diartikan bertentangan dengan hukum, untuk lebih lengkap melawan hukum merupakan perbuatan yang bertentangan dengan apa yang dibenakan oleh hukum atau perbuatan yang tidak patut dilakukan.

3. Kemampuan Untuk Bertanggung jawab

Pelaku atau seseorang yang melakukan perbuatan dapat bertanggung jawab atas perbuatan pidana yang dilakukannya.

4. Diancam Dengan Pidana Atau Hukuman Pidana

Perbuatan pelaku diancam dengan ketentuan sanksi yang mengatur mengenai tindak pidana yang dilakukan pelaku.

Segala sesuatu perlanggaran yang dilakukan oleh seseorang yang berada di Kawasan negara Replublik Indonesia diatur dalam buku II Kitab Undang- Undang Hukum Pidana (KUHP). Tindak pidana ini diakibatkan oleh kesenjangan sosial dalam masyarakat dan perokonimian masyarakat yang tidak setara bahkan susah memnuhi kebutuhan hidup sehari-hari, serta rasa malu akan keadaan kehidupannya (gengsi), Maka banyak terjadinya tindak pidana yang dilakukan oleh manusia, melihat banyaknya penduduk di Indonesia yang jauh dari kata sejahtera.

Kehidupan yang semakin hari semakin susah, lapangan pekerjaan yang sedikit mengakibatkan banyaknya masyarakat yang menganggur. Sehingga untuk mendapatkan uang dan memenuhi kebutuhan hidup diri sendiri maupun kebutuhan keluarga sangatlah susah. Ini mengakibatkan seseorang melakukan kejahatan untuk mendapat penghasilan digunakan untuk memenuhi kebutuhan hidup. Di Indonesia banyak terjadi tindak pidana yang khususnya tindak pidana begal, tindak pidana begal merupakan kejahatan yang sering dilakukan dikalangan pelaku yang perekonomiannya tergolong susah.

Dalam Kitab Undang-undang Hukum Pidana (KUHP) tidak terdapat penjelasan lebih lanjut mengenai begal, dalam KUHP tidak mengenal adanya Interpretasi dan tidak terjaminnya kepastian 
hukum, namun dalam praktek dilapangan dikenal akan adanya Interpretasi untuk dapat menjerat atau mempertanggungjawabkan perbuatan pelaku, dalam hal mencari pengertian dan pengaturan tindak pidana begal dapat dilakukan dengan cara Interpretasi memperluas pengertian begal, Interpretasi bertujuan untuk mengetahui pengertian objektif dari apa yang termasuk dalam aturan hukum bukan pengertian subyektif seperti yang dimaksud oleh pembentuk aturan pada waktu peraturan tersebut dibuat oleh Suharto (1996).

Tindak pidana begal yang dilakukan Interpretasi memperluas pengertian, termasuk dalam tindak pidana kejahatan harta benda yang terdapat dalam buku II KUHP, mulai dari pasal 362 sampai pasal 367 mengenai pencurian, dari pasal 362 sampai pasal 367 tindak pidana begal termasuk dalam pasal 365 KUHP yang dimana dalam prakteknya telah dilakukan Interpretasi memperluas pengertian. Setiap perbuatan atau tindak pidana diatur dalam Kitab Undang- Undang Hukum Pidana (KUHP). Namun dalam KUHP juga diatur mengenai alasan-alasan seseorang yang melakukan tindak pidana dapat dihapuskan. Alasan penghapus pidana adalah peraturan yang terutama ditujukan kepada hakim. Hakim dalam hal ini berwenang dalam mengadili perkara yang konkret sebagai penentu akan keadaan pelaku khususnya penghapusan pidana.

Dilihat dari perbuatan pelaku yang sudah memenuhi semua unsur-unsur yang dirumuskan dalam peraturan perundang-undangan, namun ada beberapa alasan yang dapat menyebabkan pelaku tindak pidana atau pengecualian terhadap pelaku tindak pidana dalam penjatuhan sanksi pidana yang telah dirumuskan. Alasan penghapus pidana terjadi dapat dibagi dua yaitu alasan penghapus pidana yang merupakan alasan pemaaf, dan yang kedua alasan penghapus pidana yang merupakan alasan pembenar. Alasan pemaaf adalah alasan menghapuskan pidana dari diri pelaku yang menyangkut mengenai diri pribadi pelaku. Sedangkan alasan pembenar adalah alasan menghapuskan pidana terkait perbuatan yang bersifat melawan hukum, yang menyangkut pelaku melakukan perbuatan tersebut. Alasan pemaaf dan alasan pembenar diberikan kepada seseorang dikarenakan dalam diri seseorang muncul rasa penyesalan atau mengundurkan diri secara sukarela, sehingga tidak dapat dituntut maka secara otomatis alasan penghapusan pidana.

Perbuatan pidana yang yang termasuk dalam alasan pengapusan pidana terdapat dalam buku I KUHP tentang Aturan Umum yaitu :

1. Pembelaan terpaksa (pasal 49 ayat (1) KUHP)

Dari pasal 49 KUHP dapat diartikan pembelaan terpaksa adalah perbuatan seseorang yang melanggar hukum atau melawan hukum untuk melindungi diri sendiri, orang lain, kehormatan, harta benda milik diri sendiri maupun orang lain. Pembelaan terpaksa dilakukan hanya sebatas keperluan dan keharusan tidak boleh lebih dari ancaman atau serangan yang diterima.

2. Pembelaan terpaksa melampaui batas (pasal 49 ayat (2) KUHP)

Tidak jauh berbeda dengan pembelaan terpaksan pada pasal 49 ayat (1) KUHP, pembelaan terpakasa dilakukan oleh pelaku melakukan perbuatan atau pembelaan yang dilakukan melebihi ancaman yang diterima, ini diakibatkan karena kejiawaan pelaku yang terguncang seperti emosi.

Sesuai dengan penjelasan pasal 49 KUHP terdapat unsur-unsur yang harus terpenuhi seseorang yang melakukan pembelaan terpaksa untuk penghapusan pidana atau memperingankan hukumannya yaitu: (1). Pembelaan yang dilakukan harus terpaksa, (2). Pembelaan yang dilakukan untuk diri sendiri, orang lain, kehormatan, kesusilaan, dan harta benda, (3). Harus adanya serangan atau ancaman, (4). Serang tersebut bersifat melawan hukum. Selain pembelaan terpaksa terdapat juga alasan penghapusan pidana didalam KUHP yaitu:

1. Daya paksa

yang dapat artikan suatu keadaan yang dimana keadaan tersebut diluar kemampuan manusia, terdapat dalam pasal 48 KUHP. Daya paksa merupakan suatu paksaan yang sedemikian rupa menekan seseorang, sehingga ia berada dalam keadaan yang serba salah, suatu keadaan yang memaksa dia mengambil suatu sikap dan perbuatan yang pada kenyataannya melanggar Undang-Undang yang bagi setiap orang normal tidak akan mengambil sikap dan berbuat lain berhubung resiko dari pilihan perbuatan itu lebih besar terhadap dirinya (Chazawi, 2002).

2. Menjalankan Ketentuan Undang-undang 
Menjalankan perintah sesuai dengan ketentuan Undang-Undang meskipun perbuatan tersebut merupakan melawan hukum atau merupakan tindak pidana, namun dilakukan atas dasar perintah peraturan perundang-undangan terhadap sipelaku tidak dapat dihukum, sepanjang perbuatan tersebut berdasarkan kepentingan umum bukan kepentingan pribadi. Pengaturan ini terdapat pada pasal 50 KUHP.

3. Menjalankan Perintah Jabatan yang Sah

Seseorang yang melakukan atau menjalankan suatu perintah dari suatu jabatan atau penguasa yang sah diberikan kewenangan dari Undang-Undang untuk melakukan sesuatu perintah yang bersifat tindak pidana itu tehadap si penerima perintah tidak dapat diberi hukuman. Pengaturan hal ini terdapat pada pasal 51 KUHP.

4. Pelaku yang belum dewasa

Pada pasal 45 KUHP yang bukan termasuk alasan pemaaf dan alasan pembenar sehingga bukan termasuk dalam alasan penghapusan pidana namun tidak dapat dipidana Pelaku yang belum berumur 16 tahun melakukan tindak pidana tidak dapat dijatuhi hukuman. Dalam KUHP usia yang dapat dikatakan usia anak yaitu di bawah atau yang belum berumur 16 tahun, Perbuatan pidana yang dilakukan oleh seorang yang belum genap berusia 16 tahun itu tidak dapat dipidana.

\section{Perlindungan Hukum terhadap Pelaku Pembunuhan Begal atas Dasar Pembelaan Terpaksa}

Tindak pidana yang dilakukan oleh seseorang tidak semata-mata perbuatan tersebut adalah suatu perbuatan tersebut dapat dipidana. Melakukan tindak pidana dapat didasarkan pada kebutuhan yang mendesak, perintah seseorang, dan melindungi dirinya. Dalam prakteknya semua alasan yang dilakukan pelaku tindak pidana harus mendapatkan sanksi melihat ada perbuatan yang ada akibat hukumnya sehingga dapat dipertanggungjawabkan.

Pertanggungjawaban ini harus disesuaikan kemampuan seseorang yang dapat bertanggung jawab. Tidak semua pelaku pidana dapat dihukum dan dijatuhi hukuman, namun perlu dilihat alasanalasan pelaku melakukan tindak pidana tersebut. setiap seseorang yang mendapat perlindungan hukum dari negara dan diakui oleh negara agar setiap orang merasa terlindungi keamanannya oleh hukum.

Perlindungan hukum yang dimaksud adalah suatu aturan yang memberikan pengayoman hak asasi manusia kepada kepada seseorang yang dirugikan dan termasuk masyarakat lain. Dalam kasus pembegalan, pelaku begal yang ingin merampas semua harta benda milik korbannya dan untuk menutupi aksinya atau mempermudah aksinya pelaku begal juga melakukan kekerasan terhadap korbannya, sehingga korban mengalami luka-luka hingga yang lebih keras mengakibatkan kematian. Namun jika keadaan berbalik, dalam hal ini korban yang merasa terancam melakukan pembelaan diri sehingga perbuatan pembelaan diri tersebut mengakibatkan pelaku terluka bahkan hingga meninggal sehingga perbuatan yang membela diri dari korban dijadikan tersangka. Menurut pendapat Soesilo (1993)pembelaan diri yakni: Dalam pembelaan darurat atau noodweer artinya "pembelaan darurat" supaya orang mengatakan bahwa dirinya dalam "pembelaan darurat" tidak dapat dihukum Soesilo (1993).

Pasal 49 KUHP sebagai dasar hukum untuk perlindungan hukum bagi seseorang yang melakukan pembelaan diri atau pembelaan terpaksa. Dari pasal 49 KUHP tersebut perbuatan pidana pelaku mendapat alasan penghapusan pidana sehingga bebas dari segala tuntutan, jika pelaku memenuhi unsur-unsur pembelaan terpaksa yaitu:. (1). Adanya perbuatan, (2). Adanya sifat melawan hukum, (3). Kemampuan untuk bertanggung jawab, (4).Diancam pidana atau hukuman pidana. Pemberian alasan penghapusan pidana tidak lepas dari hasil pembuktian di persidangan yang memberikan atau tidak kepada tersangka alasan penghapusan pidana. Jaksa dalam hal ini sebagai penuntut umum akan memberikan dakwaan terhadap tersangka di persidangan, namun jaksa perlu melihat beberapa hak-hak dari seorang sangka yang diatur dalam pasal 50 sampai pasal 68 KUHAP.

Berbeda halnya dengan penjatuhan hukuman terhadap anak sebagai pelaku tindak pidana, yang disebut anak adalah seseorang yang belum berumur 18 tahun atau masih didalam kandungan. Anak yang melakukan tindak pidana mendapat perlindungan hukum dikarenakan anak dianggap belum mengetahui akibat hukum yang terjadi jika melakukan perbuatan pidana. Perlindungan anak dalam penjelasan Undang-Undang Nomor 23 Tahun 2002 Yaitu segala kegiatan untuk menjamin dan melindungi anak dan hak-haknya agar dapat hidup, tumbuh, berkembang, dan berpartisipasi, secara 
optimal sesuai dengan harkat dan martabat kemanusiaan, serta mendapat perlindungan dari kekerasan dan diskriminasi.

Anak yang melakukan tindak pidana atau berkonflik hukum selanjutnya pada tingkat penyidikan, penuntutan dan pemeriksaan perkara anak di pengadilan wajib diupayakan diversi. Diversi adalah pengalihan penyelesaian perkara anak dari proses peradilan pidana ke proses di luar peradilan pidana. Penjatuhan pidana bagi anak yang yang berkonflik hukum dapat dibagi menjadi 2 yaitu pemidanaan dan Tindakan. Untuk anak yang belum berusia 14 tahun hanya dapat dikenai tindakan bukan pidana, yang berupa pengembalian ke orang tua dan pembinaan di Lembaga Penyelenggaraan Kesejahteraan Sosial (LPKS).

Sedangkan anak yang berusia di atas 14 tahun dapat dijatuhi pidana dengan jenis-jenis pidana pada pasal 71 Undang-Undang Nomor 11 tahun 2012 tentang Sistem Peradilan Pidana Anak. Suatu putusan pengadilan tidak lepas dari peran hakim, pengaturan Kekuasaan hakim diatur dalam UndangUndang Nomor 48 tahun 2009. Kekuasaan kehakiman adalah kekuasaan negara yang merdeka untuk menyelenggarakan peradilan guna menegakan hukum dan keadilan berdasarkan Pancasila dan Undang-Undang Dasar Negara Republik Indonesia Tahun 1945, demi terselenggaranya Negara Hukum Republik Indonesia. Pelaksanaan kekuasaan hakim haruslah berdasarkan ketentuan dari peraturan perundang-undangan yang berlaku dan berdasarkan asas-asas pelaksanaan kekuasaan kehakiman

Pertimbangan hakim menjatuhi hukuman tidak lepas dari segala pemeriksaan dalam proses peradilan. Mulai dari awal peradilan sampai hakim menjatuhkan putusan. Mulai dari pemeriksaan alat bukti yang digunakan pelaku dalam tindak pidana, alat bukti dapat menjadi pertimbangan hakim dalam menjatuhi berat atau ringannya putusan. Hakim dalam memeriksa, mengadili dan memutuskan suatu perkara, pertama hakim dapat mencari dalam peraturan perundang-undangan yang mengatur atau terkait mengenai perbuatan pelaku yang dilakukan, jika dalam peraturan perundang-undangan kurang cukup untuk mendapatkan peraturan yang mengatur, maka hakim dapat mencari sendiri hukum yang mengatur perbuatan tersebut dengan mencari sumber-sumber hukum seperti yurisprudensi, doktrin, traktat, kebiasaan atau hukum tidak tertulis. Hakim dalam menjatuhi hukuman berdasarkan alat bukti di pengadilan, jenis-jenis alat bukti terdapat pada pasal 184 KUHAP yaitu: (1).Keterangan saksi, (2).Keterangan ahli, (3).Surat, (4).Petunjuk, (5)Keterangan terdakwa. Selain hakim melihat alat-alat bukti, hakim juga mempertimbangkan alasan pelaku yaitu: (1).Kesalahan pembuat pidana, (2).Motif dan tujuan melakukan tindak pidana, (3).Cara melakukan tindak pidana. (4).Sikap batin si pembuat, (5).Riwayat hidup dan keadaan sosial ekonomi pembuat tindak pidana, (6).Pengaruh tindak pidana terhadap masa depan pembuat tindak pidana, (7).Sikap dan Tindakan pembuat sesudah melakukan tindak pidana, (8).Pandangan masyarakat terhadap tindak pidana yang dilakukan, (9).Tanggung jawab pelaku terhadap korban, (10).Apakah Tindakan pidana dilakukan dengan rencana.

\section{SIMPULAN DAN SARAN}

\section{Simpulan}

Perbuatan pidana yang dilakukan oleh seseorang dalam kondisi terancam sehingga melakukan pembelaan diri atau pembelaan terpaksa, sesuai dengan sesuai dengan ketentuan pasal 49 Kitab Undang-Undang Hukum Pidana, korban tindak pidana pembegalan yang melakukan pembelaan diri terhadap pelaku begal itu tidak dapat dipidana, seseorang yang melakukan pembelaan terpaksa mendapat alasan penghapusan pidana yang dapat memperingan hukuman, seseorang yang melakukan pembelaan terpaksa haruslah memenuhi unsur-unsur pembelaan terpaksa yaitu (1). Adanya perbuatan, (2). Adanya sifat melawan hukum, (3). Kemampuan untuk bertanggung jawab, (4).Diancam pidana atau hukuman pidana. Perlindungan Hukum terhadap pelaku pembunuhan pembelaan terpaksa terdapat pada pasal 49 KUHP, dan melalui pemeriksaan dalam persidangan yang menujukan buktibukti dan keterangan saksi-saksi terdapat pada pasal 184 Kitab Undang-Undang Hukum Acara Pidana yang dapat meperingan hukuman atau alasan penghapusan pidana dalam melakukan pembelaan terpaksa dalam penjatuhan hukumam. Untuk anak yang melakukan tindak pidana pembegalan diadili sesuai dengan Undang- undang Nomor 11 Tahun 2012 tentang Sistem Peradilan Pidana Anak. Penjatuhan hukuman terdapat pada hakim, hakim yang berwenang memutuskan penjatuhan pidana pada pelaku sesuai dengan pertimbangan dalam proses memeriksa, mengadili, dan memutus. 


\section{Saran}

Berdasarkan hasil penelitian, ada beberapa saran yang perlu disampaikan kepada beberapa pihak, yaitu: pertama, kepada hakim sebagai penegak hukum, untuk lebih memperhatikan setiap orang yang melakukan pembelaan terpaksa, khususnya hakim harus mempertimbangkan dalam memutuskan hukuman agar terciptanya keadilan sosial. Selanjutnya, kepada masyarakat, saat mengalami tindak pidana begal, masyarakat harus berani dalam mempertahankan diri dengan cara melakukan pembelaan diri untuk melindungi hak-hak yang perlu dipertahankan. Terakhir, kepada pelaku pembelaan terpaksa, dalam terjadi tindak pidana pelaku pembelaan terpaksa dapat menjelaskan kejadian yang sebenarnya terjadi kepada penegak hukum atas perbuatan yang dilakukan.

\section{DAFTAR PUSTAKA}

Chazawi, A. (2002). Pelajaran Hukum Pidana II. Jakarta: Rajawali Pers.

Dumgair, W. (2016). Pembelaan Terpaksa (Noodweer) dan Pembelaan Terpaksa yang Melampaui Batas (Noodweer Axces) sebagai Alasan Penghapus Pidana. Lex Crimen, 5(5), 61-68.

Marselino, R. (2020). Pembelaan Terpaksa yang Melampaui Batas (Noodweer Exces) Pada Pasal 49 Ayat (2). Jurist-Diction, 3(2), 633.

Moeljatno. (2007). Asas-Asas Hukum Pidana. Jakarta: Bina Aksara.

Pratiwi, D. K., Ariani, D., \& Heryansyah, D. (2019). Pengenalan Hak-Hak Konstitusional Warga Negara di Sekolah. JAMALI, 1(1), 24-33.

Sastrawidjaja, S. (1990). Hukum Pidana 1. Bandung: CV. Armico.

Soesilo. (1993). Kitab Undang-Undang Hukum Pidana (KUHP) serta Komentar- Komentarnya Lengkap Pasal demi Pasal. Bogor: Politeia.

Suharto. (1996). Hukum pidana Materiil. Jakarta: Sinar Grafika.

Tabaluyan, R. R. (2015). Pembelaan Terpaksa yang Melampaui Batas menurut Pasal 49 KUHP. Lex Crimen, 5(6), 26-35.

Usman, A. H. (2014). Kesadaran Hukum Masyarakat dan Pemerintah sebagai Faktor Tegaknya Negara Hukum di Indonesia. Jurnal Wawasan Hukum, 30(1), 26-53.

Utayo, M. (2013). Pelaku Pembunuhan yang Membela Diri dalam Mempertahankan Kehormatan dan Harta Benda. PRANATA HUKUM, 8(1), 148-155. 